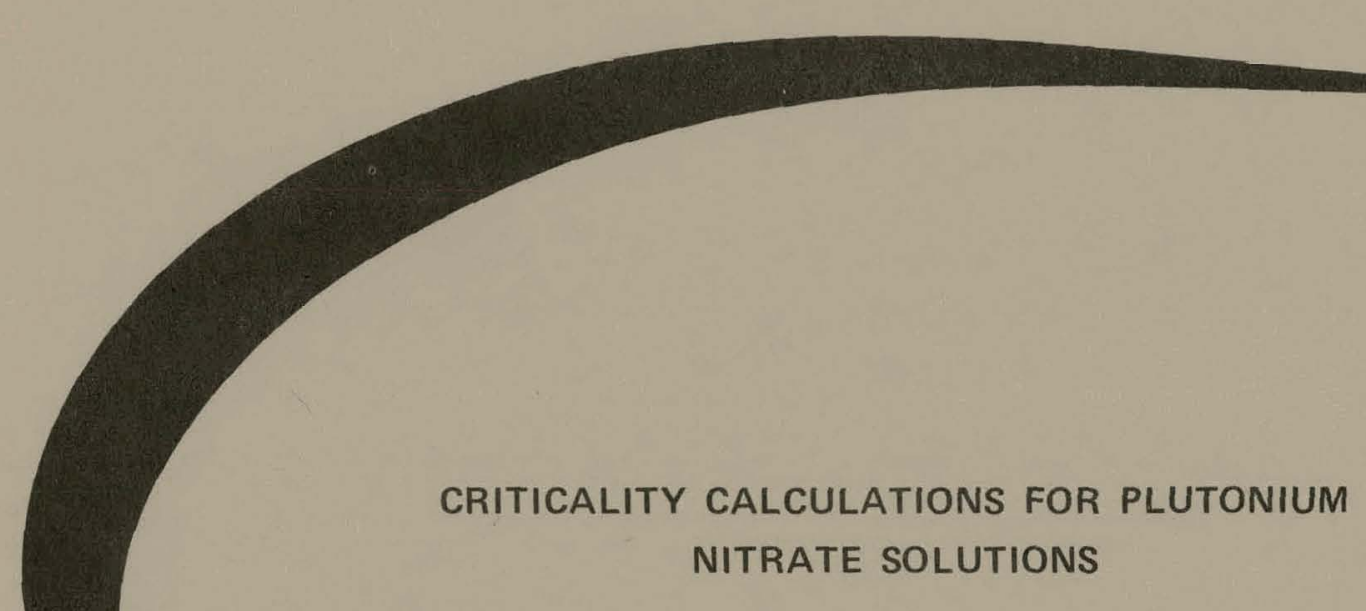

Deanne Dickinson
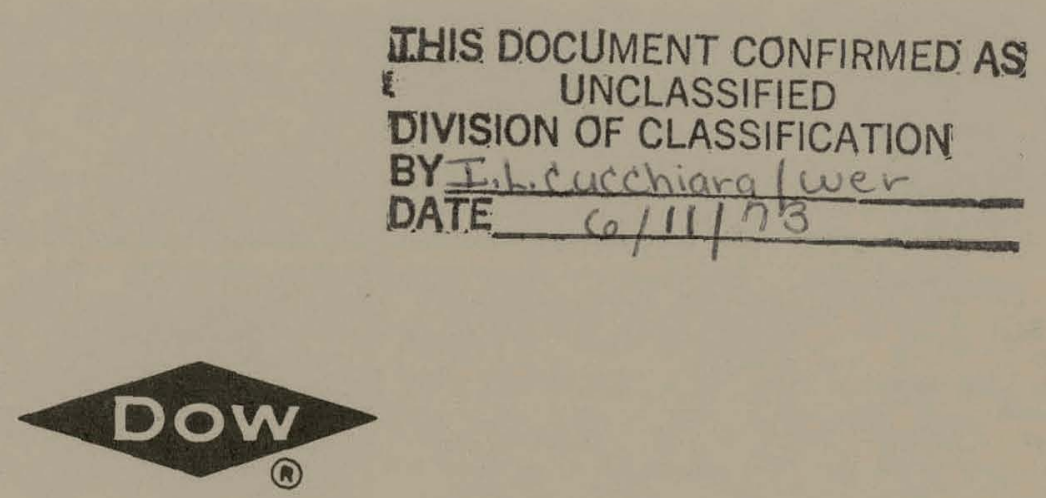

DOW CHEMICAL U.S.A. ROCKY FLATS DIVISION

P. O. BOX 888

GOLDEN, COLORADO 80401

U.S. ATOMIC ENERGY COMMISSION

CONTRACT AT(29-1)-1106 


\section{DISCLAIMER}

This report was prepared as an account of work sponsored by an agency of the United States Government. Neither the United States Government nor any agency Thereof, nor any of their employees, makes any warranty, express or implied, or assumes any legal liability or responsibility for the accuracy, completeness, or usefulness of any information, apparatus, product, or process disclosed, or represents that its use would not infringe privately owned rights. Reference herein to any specific commercial product, process, or service by trade name, trademark, manufacturer, or otherwise does not necessarily constitute or imply its endorsement, recommendation, or favoring by the United States Government or any agency thereof. The views and opinions of authors expressed herein do not necessarily state or reflect those of the United States Government or any agency thereof. 


\section{DISCLAIMER}

Portions of this document may be illegible in electronic image products. Images are produced from the best available original document. 


\section{LEGAL NOTICE}

This report was prepared as an account of work sponsured by the United States Government. Neither the United States nor the United States Atomic Energy Commission, nor any of their employees, nor any of their contractors, subcontractors, or their employees, makes any warranty, expressed or implied, or assumes any legal liability or responsibility for the accuracy, completeness or usefulness of any information, apparatus, product or process disclosed, or represents that its use would not infringe privately owned rights.

Printed in the United States of America

Available from the

National Technical Information Service

U. S. Department of Commerce

Springfield, Virginia 22151

Price: Printed Copy $\$ 3.00 ;$ Microfiche $\$ 0.95$

$\therefore \%$ 
Printed

May 9, 1973
RFP-2034

UC-46 CRITICALITY STUDIES

TID-4500 - 59th Ed.

\title{
CRITICALITY CALCULATIONS FOR PLUTONIUM NITRATE SOLUTIONS
}

\author{
Deanne Dickinson
}

NUCLEAR SAFETY GROUP

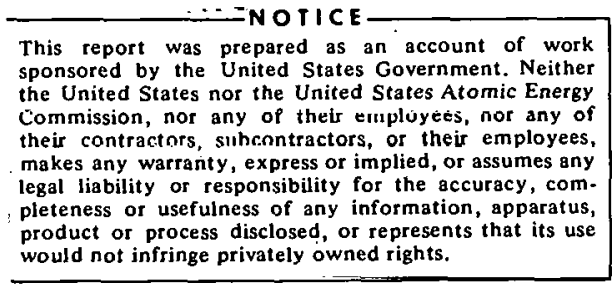

would not infringe privately owned rights.

SUBJECT DESCRIPTORS

Criticality

Plutonium Solution

Number Density

Prepared under Contract AT(29-1)-1106

for the

Albuquerque Operatiuns Orfice

U. S. Atomic Energy Commission

DOW CHEMICAL U.S.A.

P. O. BOX 888

GOLDEN, COLORADO 80401

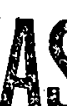

ASTER 


\section{CUN'IEN'IS}

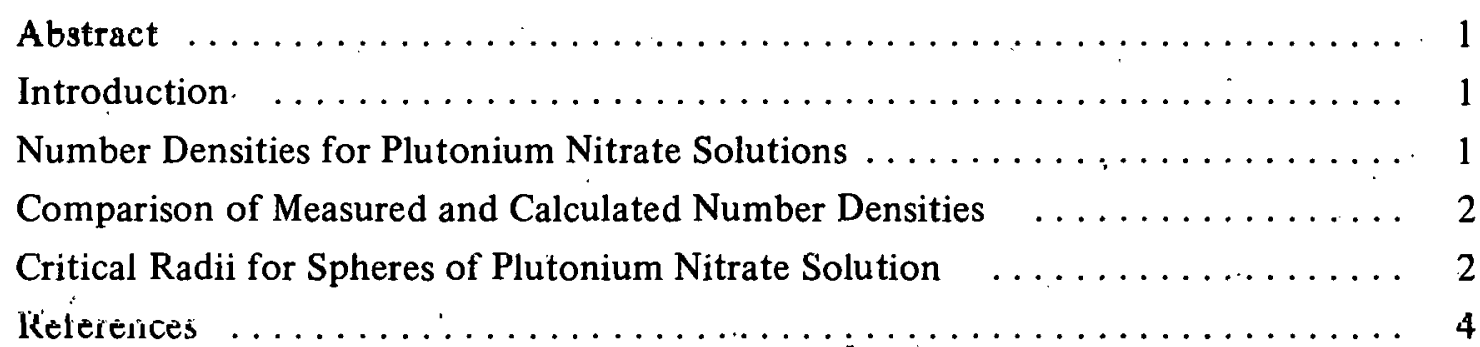




\title{
CRITICALITY CALCULATIONS FOR PLUTONIUM NITRATE SOLUTIONS
}

\author{
Deanne Dickinson
}

\begin{abstract}
Number density formulas for plutonium nitrate solution are derived with the use of an empirical formula for the water content of such solutions. The number densities given by these formulas are compared with those for actual solutions, and the effect of differences in number densities on critical dimensions is examined. Finally, the critical radii for bare spheres of plutonium solution are calculated.
\end{abstract}

\section{INTRODUCTION}

In the study of plutonium solution systems, one frequently needs to calculate number densities for a solution of a certain concentration and normality. However, the concentration and normality together are not sufficient to determine the nuclide number densities for the solution. The additional information needed is either the density of water in the solution or the total density of the solution.

Formulas for the total solution density as a function of concentration and normality have been reported by Bouly et al. (2) and Carter et al. (4). ${ }^{1}$ A formula for the density of water in plutonium nitrate solution had been given by Richey ( 8 ), and was later corrected by Richey (9). In this report, the corrected formula for the water density (9) has been used to derive number densities for hydrogen and oxygen in plutonium nitrate solutions.

\section{NUMBER DENSITIES FOR PLUTONIUM NITRATE SOLUTIONS}

The solution is assumed to be composed of plutonium nitrate [as $\left.\mathrm{Pu}\left(\mathrm{NO}_{3}\right)_{4}\right]$, nitric acid $\left(\mathrm{HNO}_{3}\right)$, and water $\left(\mathrm{H}_{2} \mathrm{O}\right)$. The amount of water in the solution is determined from the formula given by Richey (8) (9). Using a formula for water

\footnotetext{
${ }^{1}$ Numerals in parentheses relate to references at end of text.
}

density rather than one for total solution density [such as those given by Bouly and Carter $(2,4)$ ] results in simpler number density formulas. Also, the formula by Bouly (2) applies only to a limited range of concentrations and normalities.

The following symbols are used:

$$
\begin{gathered}
\mathrm{c}=\begin{array}{c}
\text { total plutonium concentration } \\
\text { in yrurrs per cubic } \\
\text { centimeter }\left(\mathrm{g} / \mathrm{cm}^{3}\right)
\end{array} \\
\text { (theta) } \theta=\begin{array}{c}
\text { weight fraction of } \\
\text { plutonium } 240\left({ }^{240} \mathrm{Pu}\right)
\end{array} \\
\mathrm{H}^{+}=\text {nitric acid normality }\left(\mathrm{NHNO}_{3}\right) \\
{[\mathrm{H}]=\begin{array}{c}
\text { number density (nuclei or molecules } \\
\text { per barn-cm) of quantity } \\
\text { in brackets }
\end{array}}
\end{gathered}
$$

From the corrected formula for water density (9), adjusted to a density of 0.9982 for pure water, one finds:

$$
\begin{aligned}
{\left[\mathrm{H}_{2} \mathrm{O}\right]=} & (0.033444)(0.9982) \\
& \left(1.0-0.3619 \mathrm{c}-0.0331 \mathrm{H}^{+}\right)
\end{aligned}
$$

From the definition of normality $(N)$ one has:

$$
\left[\mathrm{HNO}_{3}\right]=0.0006025 \mathrm{H}^{+}
$$

The number densities for the plutonium isotopes are:

$$
\begin{aligned}
{\left[{ }^{239} \mathrm{Pu}\right] } & =\frac{(1-\theta) \mathrm{c}(0.6025)}{239.0522} \\
{\left[{ }^{240} \mathrm{Pu}\right] } & =\frac{\theta c(0.6025)}{240.0540}
\end{aligned}
$$

The remaining component of the solution is the nitrate ions associated with the plutonium. Since all the plutonium is assumed to be in the tetravalent state, one has:

$$
\left[\mathrm{NO}_{3}^{-}\right]=4\left[{ }^{239} \mathrm{Pu}\right]+4\left[{ }^{240} \mathrm{Pu}\right]
$$


The hydrogen, nitrogen, and oxygen number densities are:

$$
\begin{aligned}
& {[\mathrm{H}]=2\left[\mathrm{H}_{2} \mathrm{O}\right]+\left[\mathrm{HNO}_{3}\right]} \\
& {[\mathrm{N}]=\left[\mathrm{HNO}_{3}\right]+\left[\mathrm{NO}_{3}^{-}\right]} \\
& {[\mathrm{O}]=\left[\mathrm{H}_{2} \mathrm{O}\right]+3\left[\mathrm{HNO}_{3}\right]+3\left[\mathrm{NO}_{3}^{-}\right]}
\end{aligned}
$$

The numbér density formulas, expressed in terms of $\mathrm{c}, \theta$, and $\mathrm{H}^{+}$, are summarized in Table $\mathrm{I}$.

\section{COMPARISON OF MEASURED AND CALCULATED NUMBER DENSITIES}

The hydrogen and oxygen number densities calculated from the formulas of Table I are compared with those for actual solutions in 'l'able li. "lhe water content of the actual solution was calculated from the formula:

$$
\begin{aligned}
{\left[\mathrm{H}_{2} \mathrm{O}\right]=} & 0.033444 \times \\
& \left\{\mathrm{d}-\left(\mathrm{c}+\frac{62.0049\left[\mathrm{NO}_{3}^{-}\right]}{0.6025}+0.063013 \mathrm{H}^{+}\right)\right\}
\end{aligned}
$$

Where, $d=$ total solution density in grams per cubic centimeter.

The solutions in Table III have concentrations ranging from 412 grams per liter $(\mathrm{g} / \mathrm{l})$ down to $23.4 \mathrm{~g} / \mathrm{l}$ and normalities from 3.5 to 1.3 . The concentration range includes most solutions used in critical experiments or in plutonium processing, but the range of normalities is too low to cover all of the solutions found in plant processes.

For 20 of the 26 solutions compared in Table II, the magnitude of the error in the hydrogen number density is less than $1 \%$. The large errors for 4 of the solutions described by Lloyd et al. (7) may be due to the use of the normality rather than the total nitrate to find the measured hydrogen number density. The normality computed from the measured total nitrate and other solution properties differs from the measured normality. Use of the calculated value of the normality reduced the differences between measured and calculated values of $[\mathrm{H}]$ for all of the solutions given by Lloyd (7); in particular, the error in $[\mathrm{H}]$ for the $412 \mathrm{~g} / \mathrm{l}$ solution decreased from 8.2 to 5.4 percent.
All of the errors in [H] in Table II of magnitude greater than 1 percent are positive, leading to a conservalive error in the crilical size. The largest negative error in $[\mathrm{H}]$ is -0.9 percent, and the avcrage error is 1.0 percent. The critical radius of a bare sphere was calculated for some of the solutions described in Table II in order to determine the effect on the critical size of the difference in hydrogen and oxygen number densities. These results are given in Table III. For these cases, the error in the critical radius is of opposite sign to the error in $[\mathrm{H}]$, and the magnitude of the error on the critical radius is less than or equal to the magnitude of the error in the hydrogen number density.

\section{CRITICAL RADII FOR SPHERES OF PLUTONIUM NITRATE SOLUTION}

Richey (8) reported critical dimensions for spheres, cylinders, and slabs of plutonium nitrate solution.

Because of the error in the formula for water content, the dimensions reported for systems with excess nitric acid were in error (the error is conservative, however). In this section, the formulas of Table I are used to calculate number densities for solutions with $U$ or 6 percent $240 \mathrm{Pu}, U$ or 2 normal nitric acid, and concentrations ranging from 10 to $1000 \mathrm{~g} / \ell$ of plutonium. The DTF-IV transport code (6) with Hansen-Roach six teengroup cross sections (5) was used to calculate the critical radii for these solutions. The results are presented in Table IV.

A quantity of interest in nuclear safety is the minimum critical volume for a particular type of solution. From the data of Table IV, one observes that the critical radius as a function of concentration for solutions with 0 percent ${ }^{240} \mathrm{Pu}$ is nearly constant (a change of less than $0.3 \mathrm{~cm}$ ) over the range 150 to $1000 \mathrm{~g} / \ell$. The minimum critical radius, derived from a parabolic fit to the last three data points, occurs at about $562 \mathrm{~g} / \mathrm{l}$ for solutions with 0 percent ${ }^{240} \mathrm{Pu}$ and 0 -normal $(N)$ acid, and at about $545 \mathrm{~g} / \ell$ for 0 percent ${ }^{240} \mathrm{Pu}$ and $2-N$ acid.

For solutions containing 6 percent ${ }^{240} \mathrm{Pu}$, the minimum critical radius occurs at a much lower concentration $(193 \mathrm{~g} / \ell$ for $0-N$ acid and $187 \mathrm{~g} / \mathrm{\ell}$ for $2-N$ acid), and the minimum is much more pronounced than for solutions with 0 percent ${ }^{240} \mathrm{Pu}$. 
TABLE I. Number Density Formulas for Plutonium Nitrate Solution.

Nuclide

Hydrogen (H)

Nitrogen $(\mathrm{N})$

Oxygen (O)

Plutonium 239 $\left({ }^{239} \mathrm{Pu}\right)$

Plutonium 240 $\left({ }^{240} \mathrm{Pu}\right)$
Formula for Number Density in Nuclei per Barn-Centimeter

$0.06676704-0.02415980 \mathrm{c}-0.00160478 \mathrm{H}^{+}$

$[0.01008148(1-\theta)+0.01003940 \theta] \mathrm{c}+0.0006025 \mathrm{H}^{+}$

$0.03338352+[0.03024444(1-\theta)+0.03011820 \theta-0.0120799] \mathrm{c}+0.00070386 \mathrm{H}^{+}$

$0.00252037(1-\theta) c$

$0.00250985 \theta . c$

Legend

$c=$ plutonium concentration in grams per cubic centimeter

$\theta=$ weight fraction of plutonium 240

$\mathrm{H}^{+}=$nitric acid normality

TABLE II. Comparison of Calculated and Measured Number Densities for Plutonium Nitrate Solutions.

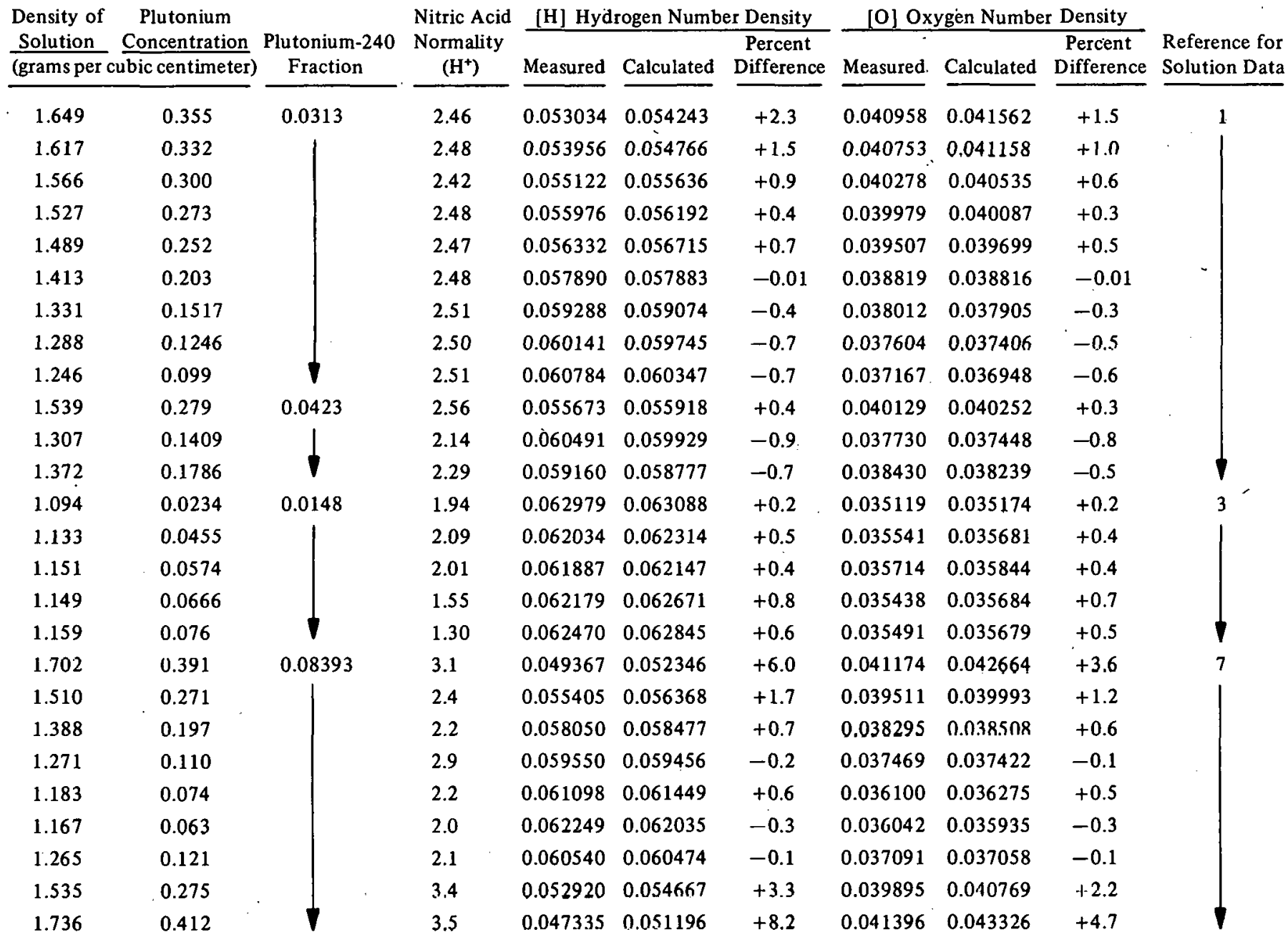


TABLE III. Critical Radii of Spheres of Plutonium Nitrate Solution Usin $\dot{\xi}_{\ddot{g}}$ the Measured or Calculated Values for the Water Content.

\begin{tabular}{c}
$\begin{array}{c}\text { Plutonium Concentration } \\
\text { (grams per cubic centimeter) }\end{array}$ \\
\hline 0.412 \\
0.355 \\
0.332 \\
0.063 \\
0.1409
\end{tabular}

\begin{tabular}{c}
$\begin{array}{c}\text { Percent Difference } \\
\text { in [H] }\end{array}$ \\
\hline+8.2 \\
+2.3 \\
+1.5 \\
-0.3 \\
-0.9
\end{tabular}

\begin{tabular}{|c|c|}
\hline \multicolumn{2}{|c|}{ Critical Radius (centimeters) for Bare Sphcrc } \\
\hline $\begin{array}{l}{[\mathrm{H}] \text { and }[\mathrm{O}] \text { from }} \\
\text { Measured Uata }\end{array}$ & $\begin{array}{l}{[\mathrm{H}] \text { and }[\mathrm{O}] \text { from }} \\
\text { Formula for }\left[\mathrm{H}_{2} \mathrm{O}\right]\end{array}$ \\
\hline 22.47 & 20.89 \\
\hline 18.54 & 18.17 \\
\hline 18.55 & 18.30 \\
\hline 19.43 & 19.49 \\
\hline 17.98 & 18.13 \\
\hline
\end{tabular}

\begin{tabular}{c}
$\begin{array}{c}\text { Percent Difference in } \\
\text { Critival Radii }\end{array}$ \\
\hline-7.0 \\
-2.0 \\
-1.4 \\
+0.3 \\
+0.8
\end{tabular}

NOTE: The critical radii were calculated using the DTF-IV transport code (6) with Hansen-Roach sixteen-group cross sections (5). $[\mathrm{H}]-$ hydrogen number density $\quad[\mathrm{O}]$ - oxygen number density $\quad\left[\mathrm{H}_{2} \mathrm{O}\right]$ - water number density

TABLE IV. Critical Radii for Unreflected Spheres of Plutonium Nitrate $\left[\mathrm{Pu}\left(\mathrm{NO}_{3}\right)_{4}\right]$ Solution.

\begin{tabular}{|c|c|c|c|c|}
\hline \multirow[b]{3}{*}{$\begin{array}{l}\text { Concentration } \\
\text { (grams per liter) }\end{array}$} & \multicolumn{4}{|c|}{ Critical Radius (cenitmeter) } \\
\hline & \multicolumn{2}{|c|}{$\begin{array}{c}\text { 0-Percent } \\
\text { Plutonium } 240\end{array}$} & \multicolumn{2}{|c|}{$\begin{array}{c}\text { 6-Percent } \\
\text { Plutonium } 240\end{array}$} \\
\hline & $\begin{array}{l}\text { 0-Normal } \\
\text { Nitric Acid }\end{array}$ & $\begin{array}{l}\text { 2-Normal } \\
\text { Nitric Acid }\end{array}$ & $\begin{array}{l}\text { O-Normal } \\
\text { Nitric Acid }\end{array}$ & $\begin{array}{l}\text { 2-Normal } \\
\text { Nitric Acid }\end{array}$ \\
\hline 10 & 38.836 & 43.030 & 46.066 & 52.783 \\
\hline 15 & 26.298 & 27.846 & .28 .662 & 30.554 \\
\hline 20 & 22.553 & 23.644 & 24.164 & 25.438 \\
\hline 35 & 18.865 & 19.598 & 20.010 & 20.636 \\
\hline 50 & 17.676 & 18.324 & 18.842 & 19.581 \\
\hline 150 & 16.224 & 16.768 & 17.813 & 18.470 \\
\hline 200 & 16.061 & 16.585 & 17.792 & 18.462 \\
\hline 450 & 15.965 & 16.489 & 18.542 & 19.251 \\
\hline 1000 & 16.110 & 16.661 & - & - \\
\hline
\end{tabular}

\section{REFERENCES}

1. Francis Barbry, Jean-Claude Bouly, Robert Caizergues, Edouard Deilgat, Michel Houelle, and Pierre Lecorché. Etude Expérimentale et Théoretique de l'Empoisonnement Héterogene de Solution de Matiere Fissile par des Tubes ou des Anneaux en Verre au Borosilicate.

CEA-R-3931. Centre d'Etudes Nucléaires de Saclay, Saclay, France. Décembre 1969.

2. Jean-Claude Bouly, Robert Caizergues, Edouard Deilgat, Michel Houelle, and Pierre -Lecorché, Expériences de Criticité Réalisées avec une Solution Homogéne de Plutonium. Résultats Expérimentaux. Interprétations Théoretiques, CEA-R-3367, Centre d'Etudes Nucléaires de Saclay, Saclay, France. Décembre 1967.
3. Jean-Georges Bruna, Jean-Paul Brunet, Robert Caizergues, Christian Clouet d'Orval, Jacques Kremser, Henry Tellier, and Phillippe Verriere. ALECTO - Résultals des Ex́periences Critiques Homogénes Réalisées sur le ${ }^{239} \mathrm{Pu},{ }^{235} \mathrm{U}$, et ${ }^{233} U$. CEA-R-2814. Centre d'Etudes Nucléaires de Saclay, Saclay, France. Octobre 1965.

4. R. D. Carter, G. R. Kiel, and K. R. Ridgway. Criticality Handbook, Volumes I and II (Revision 1). ARH-600. Atlantic-Richfield Hanford Company, Richland, Washington. June 28, 1968.

5. Gordon E. Hansen and William H. Roach. Six and Sixteen Group Cross Sections for Fast and Intermediate Critical Assemblies. LAMS-2543. Los Alamos Ścientific Laboratory, Los Alamos, New Mexico. December 1960.

6. K. D. Lathrop. DTF-IV, A FORTRAN-IV Program for Solving the Multigroup Transport Equation with Anisotropic Scattering. LA-3373. Los Alamos Scientific Laboratory, Los Alamos, New Mexico. November 12, 1965.

7. R. C. Lloyd, S. R. Bierman, and E. D. Clayton. "Criticality of Plutonium Nitrate Solutions Containing Borated Raschig Rings." Nuclear Science and Engineering, 50:127. 1973.

8. C. R. Richey. "Theoretical Analysis of Homogeneous Plutonium Critical Experiments." Nuclear Science and Engineering, 31:32. 1968.

9. C. R. Richey. "Corrigendum." Nuclear Science and Engineering, 49:246. 1972. 